Ana Vujošević ${ }^{1}$, Srdjan Matijašević ${ }^{2 *}$, Sonja Smiljanić ${ }^{3}$, Jelena Nikolićí, Bogoljub Zečević, ${ }^{4}$, Vladimir Topalović ${ }^{2}$, Veljko Savić ${ }^{2}$

${ }^{1}$ University of Belgrade, Faculty of Agriculture, Zemun, Serbia

${ }^{2}$ Institute for Technology of Nuclear and Other Mineral Raw Materials (ITNMS), Belgrade, Serbia, ${ }^{3}$ University of Belgrade, Faculty of Technology and Metallurgy, Belgrade, Serbia

${ }^{4}$ Institute for Vegetable Crops, Smederevska Palanka, Serbia
Scientific paper

ISSN 0351-9465, E-ISSN 2466-2585

UDC:631.461.7

doi:10.5937/zasmat1901096V

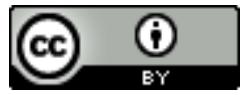

Zastita Materijala 60 (1)

96 - 104 (2019)

\title{
Polyphosphate glass as fertilizer for plant seedlings
}

\begin{abstract}
Due to the dissolution properties the phosphate glasses can be promising materials for the development of new ecologically safe fertilizers. The complex polyphosphate glass with a molar ratio $\left(\mathrm{M}_{2} \mathrm{O}+\mathrm{MO}\right) / \mathrm{P}_{2} \mathrm{O}_{5}>1$ and addition of microelements $\mathrm{Zn}^{2+}, \mathrm{Mn}^{2+}, \mathrm{Fe}^{3+}$ and $\mathrm{Cu}^{2+}$ were used in substrate for production of flower and vegetables seedlings. Dissolution tests were conducted in deionized water and $2 \%$ citric acid. The effects of the reaction time on the normalized glass mass loss $\left(f_{m}\right)$ and the normalized concentrations of the ions $\left(f_{i}\right)$ at $20,30,37$ and $50^{\circ} \mathrm{C}$ were determined. Dissolution rate constants $\left(k_{w}\right.$ - deionized water, $k_{c}-2 \%$ citric acid) were also determined $\left(k_{w}-0.0028-0.0094 \mathrm{gm}^{-2}, k_{c}-0.029-0.011 \mathrm{gm}^{-2}\right)$. Values of $k_{c}$ were higher than those of $k_{w}$, which confirms a significant effect of solvent type and temperature on the dissolution kinetics of glass. The experiments with plants (one vegetable and one flower) showed that the addition of phosphate glass caused an increase in yield and quality of plants. The applied dose of polyphosphate glass of $1 \mathrm{gl}^{1}$ showed the best effect on the growth of the examined plant seedlings.
\end{abstract}

Keywords: polyphosphate glass, substrata, plant, seedlings.

\section{INTRODUCTION}

The chemical composition of various essential minerals and elements meant for the regular as well as hastened growth and nourishment of all plants is termed as fertilizer. All the fertilizers have been categorized into several types depending on their constituents, strength and various other features (organic, inorganic, macronutrients, micronutrients, eco-friendly, controlled release, glassy fertilizers etc) [1-3].

The pure phosphate glass (vitreous $\mathrm{P}_{2} \mathrm{O}_{5}$ ), is highly hygroscopic and is not appropriate for application. The properties of this glass can be improved by addition of different network modifier alkali and alkaline earth oxides. In that way, the multi component phosphate- based glasses or glass-ceramics having many specific properties that can be obtained. As such, these materials can find wide technological application $[4,5]$.

\footnotetext{
${ }^{*}$ Corresponding author: Srdjan Matijašević

E-mail: s.matijasevic@itnms.ac.rs

Paper received: 02. 12. 2018.

Paper accepted: 12. 01. 2019.

Paper is available on the website: www.idk.org.rs/journal
}

As reported earlier the phosphate glasses of various compositions possess bioactivity and can be used as bio or eco-materials. Calcium phosphate glasses and glass ceramics for the bone implants in surgery and dentistry are well known biomaterials [6,7]. Recently, because of gradual solubility the attention was paid to the phosphate based glasses which can be used as a new ecologically safe fertilizers $[8,9]$. The fact is that conventional technologies for land cultivation based on application of traditional mineral fertilizers are responsible for pollution of environment.

The main advantage of glasses is the possibility to change their chemical composition by addition of new elements in different quantities. Therefore, the kinetics and mechanism of the dissolution process can be tailored as needed [10]. In the case of plant nutrition, it is important that the release rates of glass components are equal to the absorption rates of plants or microorganisms [11]. In this way, the possible damaging effects of accumulation or deficiency of elements can be avoided.

The dissolution of a glass is a complex phenomenon and the kinetics of this process result from the convolution of numerous mechanisms, most of which depend not only on the glass 
properties (composition, structure, surface condition, etc.), but also on the environment such as leaching solution volume, flow rate, temperature, $\mathrm{pH}$, etc. $[12,13]$. In the recent study, it was shown that a complex polyphosphate glass with a molar ratio $\left(\mathrm{M}_{2} \mathrm{O}+\mathrm{MO}\right) / \mathrm{P}_{2} \mathrm{O}_{5}>1$ (where $\mathrm{M}$ are the modifying cations) dissolved selectively (incongruent) without back precipitation of the secondary corrosion products [14]. The glass dissolution was conducted in deionized water and $2 \%$ citric acid, under static conditions. Based on this study, the polyphosphate glass containing $\mathrm{P}_{2} \mathrm{O}_{5}, \mathrm{~K}_{2} \mathrm{O}, \mathrm{CaO}, \mathrm{MgO}$, and $\mathrm{SiO}_{2}$ as main oxides was chosen for investigation. The glass composition was adjusted by addition of the microelements in a form of oxides $\mathrm{Zn}^{2+}, \mathrm{Mn}^{2+}, \mathrm{Fe}^{3+}$ and $\mathrm{Cu}^{2+}$. The aim of this work is to examine the effect of addition of polyphosphate glass in substrate on the growth of the selected flower and vegetable seedlings.

\section{MATERIALS AND METHODS}

\subsection{Glass synthesis}

The appropriate glass batch composition was prepared from reagent grade raw materials $\left(\mathrm{NH}_{4}\right)_{2} \mathrm{HPO}_{4}, \mathrm{~K}_{2} \mathrm{CO}_{3}, \mathrm{CaCO}_{3}, \mathrm{SiO}_{2}, \mathrm{MgO}, \mathrm{ZnO}$, $\mathrm{Fe}_{2} \mathrm{O}_{3}, \mathrm{CuO}$ and $\mathrm{MnO}_{2}$. The glass mixture was melted in an open Pt-crucible at $T=1100{ }^{\circ} \mathrm{C}$ for $t=1 \mathrm{~h}$ in an electric furnace and the melt was quenched on a steel plate and cooled in air. The chemical composition of glass was determined by gravimetric and spectroscopic methods, i.e., by AAS using a PERKIN ELMER 703 instrument and UV/VIS spectroscopy using a PHILIPS 8610 spectrophotometer. The obtained glass was examined by the XRD method using a Philips PW1710 automated diffractometer with a $\mathrm{Cu}$ tube operated at $40 \mathrm{kV}$ and $30 \mathrm{~mA}$. The diffraction data were collected in the $2 \theta$ Bragg angle from $5-70^{\circ}$, counting for $1 \mathrm{~s}$.

\subsection{Glass dissolution test}

Dissolution tests were conducted in deionized water with the following characteristics: $\mathrm{pH}=6.93$, conductivity $\chi=4.91 \mu \mathrm{S} \mathrm{cm}^{-1}\left(T=25^{\circ} \mathrm{C}\right)$ and $2 \%$ citric acid $\left(\mathrm{pH}=2.31\right.$ and $\left.\chi=3.103 \mu \mathrm{Scm}^{-1}\right)$ which simulated the activity of organic compounds located around a plant root for extraction of the useful components from soil. The experiments were performed with glass powders of particle sizes of $0.3-0.50 \mathrm{~mm}$. The specific surface area of these powders was determined by Laser particlesizer Fritsch Analyzette 22. The glass powder was prepared by crushing the bulk glass in an agate mortar and sieved to appropriate grain sizes. This powder was washed with distilled water and then dried in an electric dryer at $T=105^{\circ} \mathrm{C}$ for $t=3 \mathrm{~h}$. The sample was stored in a desiccator.

The glass powders $(1 \mathrm{~g})$ were weighed and transferred into $50 \mathrm{ml}$ plastic volumetric flasks and then deionized water $/ 2 \%$ citric acid was added. The closed flasks were placed in a water bath. The experiments were performed at temperatures of 20 , 30,37 and $50^{\circ} \mathrm{C}$ for different times in the range 0.5 to $720 \mathrm{~h}$. After completion of each experiment, the solution and remaining glass were separated using a filter paper and afterwards the content of the present elements was determined. The remaining glass was dried at $T=105^{\circ} \mathrm{C}$ to the constant mass of the sample and then the mass of dissolved glass was calculated. The concentrations of the ions were determined using a PERKIN ELMER 703 atomic absorption spectrometer and a PHILIPS UV/VIS 8610 spectrophotometer.

To compare the release of different leached species as an appropriate parameter, the normalized $i$-th element mass release from unit area $\left(f_{i}\right)$ was used [15-19]:

$$
f_{i}=\frac{c_{i} \cdot V}{\delta_{i} \cdot S}
$$

where $c_{i}$ is the mass concentration of a particular leached species in time $t, \delta_{i}$ is the mass fraction of a species $i$ in the glass, $S$ is the glass surface in contact with the solution and $V$ is the solution volume.

\subsection{Substrate characteristics}

The substrate used in the experiments were standard plant growing substrate (Floragard Floradur $B$ Pot Medium-Coarse) suitable for medium-sized pots of approx. 8-11 $\mathrm{cm}$ and bedding plants of a balanced composition of macro and micronutrients which were chemically and physically tested. Total porosity of substrate $(86.90$ $\%)$ was calculated using bulk density and bulk volume. Bulk volume $\left(0.199 \mathrm{gcm}^{-3}\right)$ was determined by cylinders Kopecky of $100 \mathrm{~cm}^{3}$. Bulk density $\left(1.52 \mathrm{gcm}^{-3}\right)$ was determined from xylol, using the Alber-Rogs method. Active acidity 5.13 to $6.35 \mathrm{pH}$ in water) was measured in the substrate water suspension using a potentiometer. Content of humus $(68.47 \%)$ and the total of nitrogen $(0.798$ $\%)$ is high. According to its physical and chemical characteristics, substrate were suitable for production of seedlings.

\subsection{Experiments on plants}

The study was performed in a greenhouse with a common flower and a domestic vegetable as test plants: a) marigold (Tagetes patula "Bolero") and b) pepper (Capsicum annum "Župska rana"). The 
species were selected based on availability and appropriate length of their vegetation period.

Seeds were sown in polypropylene containers (TEKU type 144/4.5). For initial seedling growth Floragard Floradur B-seed was used. During the initial seedling production, no additional nutrients were applied. With the appearance of two pairs of permanent leaves (4 weeks after seeding), the plants were transplanted individually in round pots (TEKU $\varnothing 9 \mathrm{~cm}$, i.e., volume of $0.32 \mathrm{l}$ ) in a substrate (Floragard Floradur B Pot Medium-Coarse) where the polyphosphate glass powder of a particle size < $0.5 \mathrm{~mm}$ was added as follows: 0, 1, 2, 3 and $4 \mathrm{~g}$ per liter of substrate. For each species tested, as well as each variant of the test, 30 plants were transplanted. The glass powder was mixed with the substrate according to target dose and then filled into the pots. On average, 11 of substrate was sufficient for 4 pots of this volume. The selected initial seedlings were manually transplanted in pots. Plant seedlings were produced while continuously monitoring and maintaining the temperature of air $\left(20-24^{\circ} \mathrm{C}\right.$ ), substrate (above $18^{\circ} \mathrm{C}$ ), as well as the optimum temperature for development of the plant seedlings in general. During the growth experiment, no additional nutrition was provided apart from the initial content in the respective substrates. At the end of the production cycle, after 6 weeks for Tagetes and 9 weeks for Capsicum, growth parameters analyzed were: a) above- ground plant mass and b) root mass. Also, in the control variant of the substrate (without an added glass powder) at the end of the vegetation period, values of $\mathrm{pH}-6.35$ and $\chi=0.132 \mathrm{mScm}^{-1}$ were determined.

The obtained results were analyzed using the descriptive and analytical statistics. The arithmetical mean and standard error, interval of variation (Iv), coefficient of variation ( $\mathrm{Cv}, \%)$, and median (Me), were defined. It was considered that the average values of analyzed characteristics of plants would not differ regarding the addition of different quantities of polyphosphate glass and this hypothesis was tested. The optimal dose of polyphosphate glass regarding the effects on the growth parameters of plants-seedlings was determined by means of synthetic grade using the total discrimination effect established by the Ivanovic distance [20]. I-distance (method) represents capability to integrate a large number of different measures variables into one value $[21,22]$. Statistical analysis of the results obtained in the experiment was carried out using the software STATISTICA v. 6 (StatSoft, Inc., Tulsa, OK, USA).

\section{RESULTS AND DISCUSION}

The result of the chemical analysis of phosphate glass obtained (Tab. 1) showed that the polyphosphate glass was an appropriate material for usage in substrate for plant production.

Table 1. Composition of the glass

Tabela 1. Hemijski sastav dobijenog stakla

\begin{tabular}{|c|c|c|c|c|c|c|c|c|c|}
\hline \multicolumn{10}{|c|}{ Oxide [mol \%] } \\
\hline & $\mathrm{P}_{2} \mathrm{O}_{5}$ & $\mathrm{SiO}_{2}$ & $\mathrm{~K}_{2} \mathrm{O}$ & $\mathrm{CaO}$ & $\mathrm{MgO}$ & $\mathrm{ZnO}$ & $\mathrm{MnO}_{2}$ & $\mathrm{Fe}_{2} \mathrm{O}_{3}$ & $\mathrm{CuO}$ \\
\hline Anal. & 44.8 & 3.7 & 24.4 & 12.4 & 7.4 & 1.9 & 1.8 & 1.9 & 1.7 \\
\hline
\end{tabular}

Powder X-ray diffraction (XRD) analysis confirmed the quenched melt to be vitreous (Fig.1).

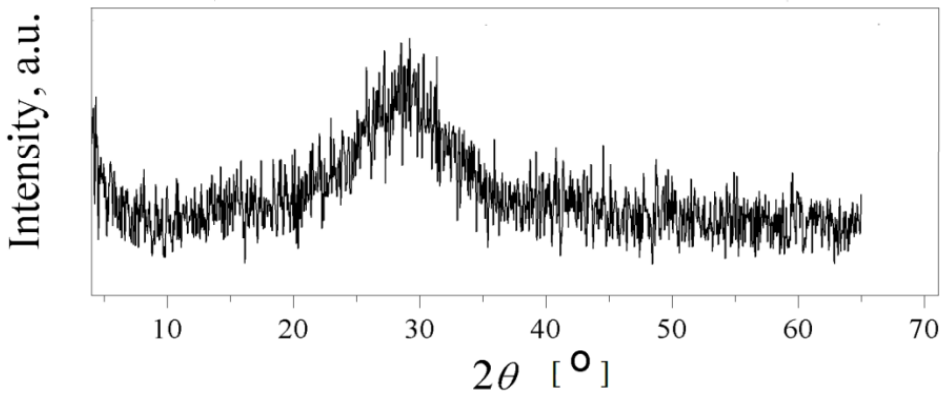

Figure 1. XRD of bulk glass

\section{Slika 1. XRD analiza uzorka stakla}

\subsection{Dissolution kinetics of glass}

The dissolution tests showed that this glass dissolved without back precipitation of the second- dary corrosion products. Using the experimentally determined mass losses $(\Delta m)$, the specific surface area of the glass powder $S=0.0178 \mathrm{~m}^{2} \mathrm{~g}^{-1}$ and the 
volume of leaching solution $V$, the normalized mass release $f_{m}\left[\mathrm{~g} \mathrm{~m}^{-2}\right]$ was calculated (Fig. 2) [23].

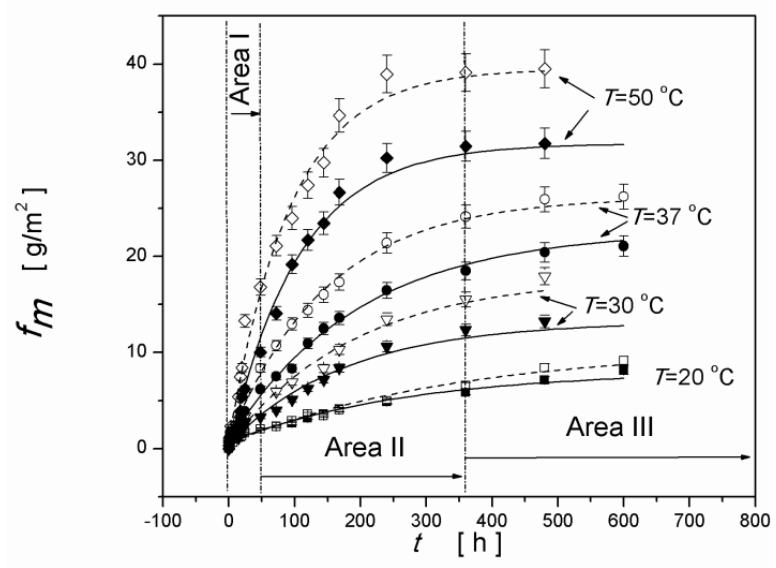

Figure 2. The time dependence of $f_{m}$ for glass powder sample of particle size of $0.30-0.50 \mathrm{~mm}$ at different temperatures (-deionized water) and (----2\% Citric acid)

Slika 2. Promene normalizovanog gubitka mase sa vremenom $\left(f_{m}\right)$ za uzorak stakla granulacije 0.30 -

$0.50 \mathrm{~mm}$ na različitim temperaturama (dejonizovana voda) $i$ (----2\% limunska kiselina)

Regarding the changes of $f_{m}$, three different areas can be distinguished (Fig. 2). At the beginning the changes of $f_{m}$ were linear with time and the rates of glass dissolution under given conditions were the highest. This linear area was followed by an intermediate area where the changes of $f_{m}$ became slower with increasing time and the dissolution rate of the glass decreases. For longer periods of time, the changes of $f_{m}$ were very small. Also, it may be noticed that there was a difference in the $f_{m}$ values depending on the type of solvent used. With increasing the temperature, the difference between curves increases.

The values of $k_{c}$ were higher than those of $k_{w}$, which confirms a significant effect of solvent type and temperature on the dissolution kinetics of glass (Fig. 3).

This suggests that the protons in acid medium had a strong influence on P-O-M bond dissociation in glass ( $M$ - network modifier cations), which resulted in an increase of hydration and glass dissolution rates. Based on the experimentally measured ion concentrations, the normalized ion concentrations in the solution, $f_{i}$, were calculated using Eq. (1). The dependences of the normalized concentrations of the ions on the dissolution time for both studied solvents are presented in Fig. 4

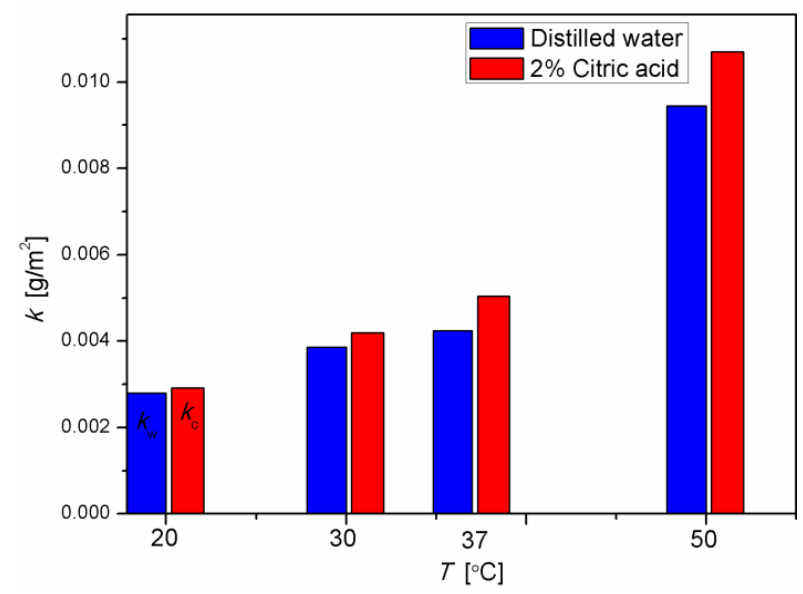

Figure 3. The dissolution rate constants $\left(k_{w}, k_{c}\right)$ calculated from $f_{m}(t)$ at different temperatures

Slika 3. Konstante brzina rastvaranja $\left(k_{w}, k_{c}\right)$ izračunatih iz $f_{m}(t)$ na različitim temperaturama
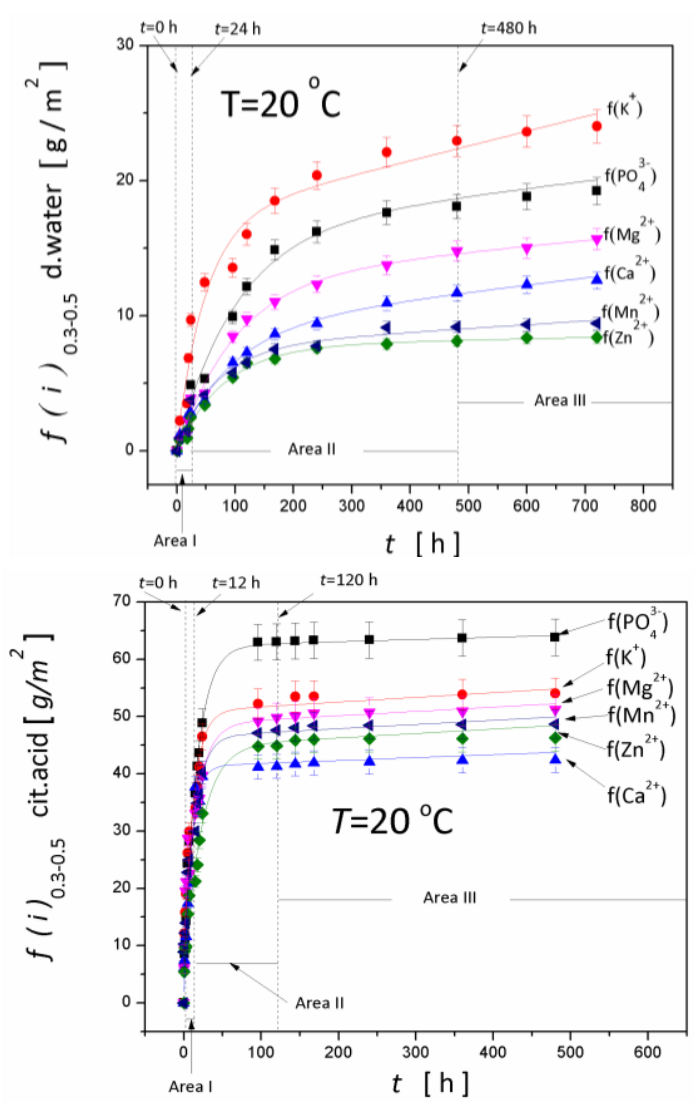

Figure 4. The time dependence of $f_{i}$ for examined ions for plant nutrition from glass at $20^{\circ} \mathrm{C}$

Slika 4. Promene normalizovanih koncentracija jona sa vremenom $\left(f_{i}\right)$ za ispitivane katjone $u$ ishrani biljaka na $T=20^{\circ} \mathrm{C}$.

For shorter dissolution times, Area I, the values of the normalized concentrations of the ions showed the biggest changes with respect to field strength and coordination environment of the 
modifier cations. This so-called "initial stage" of dissolution might be described as a linear dependence of normalized concentrations of the ions on dissolution time. For dissolution times in Area II, the "initial stage" of dissolution was followed by a "transitional stage".

The trend in the changes in the values of the normalized concentrations of the ions indicates a significant decrease in the dissolution rate of glass in the "transitional stage". In the third stage, Area III, named the "final stage", a linear dependence of the normalized concentrations of ions was observed, but the changes during the dissolution were quite small. Initial rates of dissolution were more than 10 times higher in $2 \%$ citric acid than in deionized water.

Glass dissolution is a complex process which depends on the condition of the solution and the composition and structure of the glass. This process is usually modeled as the combination of ion-exchange and matrix-dissolution reactions. In the case of congruent dissolution of a glass, the time dependencies of $f_{i}$ should be equal [24-27]. However, the time dependencies of $f_{\mathrm{i}}$ differed, showing an incongruent dissolution during the initial dissolution phase (Fig.4). Cation diffusion was a dominant process in water, while a network dissolution process was dominant in acid. The values of $f_{i}$ for $\mathrm{K}^{+}$and $\mathrm{PO}_{4}{ }^{3-}$ were the highest in both solvents, as the most important macronutrients for plant nutrition. The results of $\mathrm{pH}$ leaching solutions measurement (Fig.5), have shown that there is not abrupt change of $\mathrm{pH}$ for deionized water (6.6-6.35) because of small dissolution of alkali ions from the glass. In the case of acid solution, at the end of the dissolution process $(\mathrm{t}=500 \mathrm{~h}), \mathrm{pH}=4.16$ differences slightly regarding to the starting value of $\mathrm{pH}=3.89$.

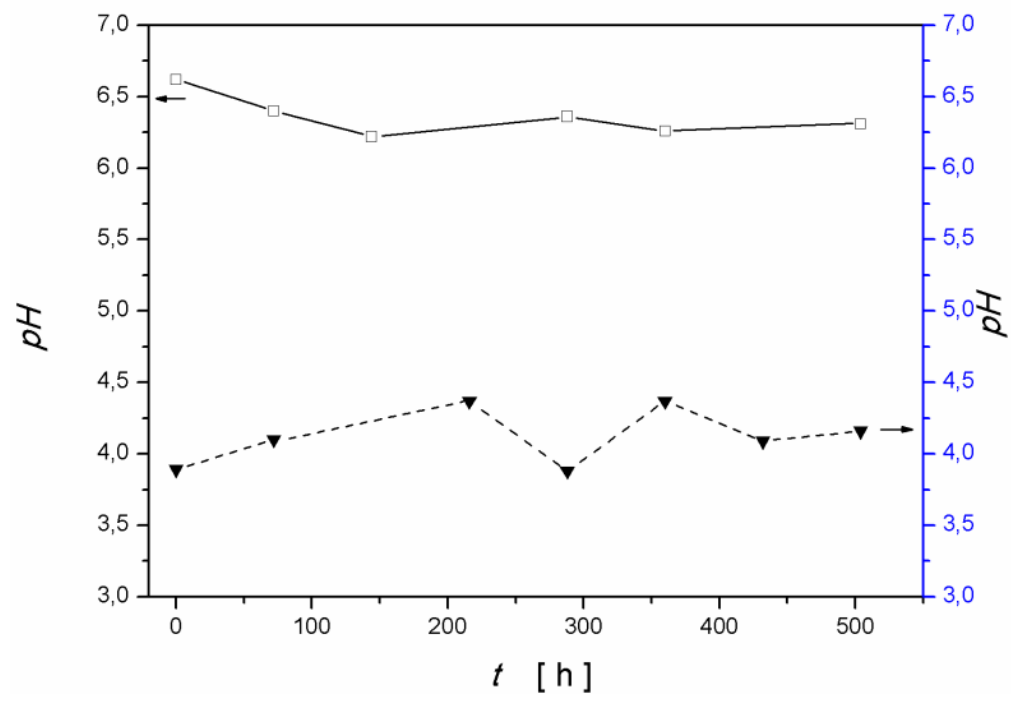

Figure 5. The time dependence of $\mathrm{pH}:$ ( - ) deionized water (---) $2 \%$ citric acid solution

Slika 5. Promene $\mathrm{pH}$ rastvora sa vremenom pri rastvaranju uzorka: ( - ) dejonizovana voda (---) 2\% limunska kiselina

In this stage the glass is fully dissolved, and all phosphate and alkali ions from the glass have passed into leaching solution.

\subsection{Adoption of minerals in plant nutrition}

After the initial stages of dissolution of glass, the process of dissolution slowed down, thus affecting the further dynamics of the adoption of elements by the plant. The dissolution rates of glass were much lower than the initial rate of dissolution. The dynamics of further release of elements from the glass depended on the rate of adoption. The plants also adopted other necessary elements ( $\mathrm{Fe}, \mathrm{Mn}, \mathrm{Zn}, \mathrm{Cu})$. The amount of the element adoption was conditioned by the time interval of the growing season of plants-seedlings. Thus, the shortest type of vegetation seedlings (6 weeks), such as Tagetes, had greater needs for nitrogen, $\mathrm{K}^{+}$and $\mathrm{PO}_{4}{ }^{3-}$ in all stages of development, compared to plants of both medium-long (8-10-12 weeks) and long growing seedlings (12-14 weeks) when there was a greater need for potassium and nitrogen in relation to phosphorus [3]. Due to the dissolution process, the glass powder releases plant nutrients in inorganic form into the soil/growing medium and can thus be considered as a type of mineral fertilizer.

In this way, glass as slow fertilizer can "manage" plants nutrition. Reducing the 
concentration of elements in the substrate supports further dissolution of the glass.

Since the greatest amounts of $\mathrm{K}^{+}$and $\mathrm{PO}_{4}{ }^{3-}$ are released at the beginning of the dissolution of glass, the importance of this designed glass is immeasurable in plants with short vegetation seedlings. For plants of longer growing seedlings, the possibility of optimal nutrition during the whole production process is possible because a dissolution rate of glass slows down with time.

This indicates that the use of studied phosphate glass composition provides a good supply of substrate with all the necessary elements for the development throughout the entire production cycle, 6 weeks for marigold and 9 weeks for pepper.

Ion adoption is influenced by their concentration in the soil solution. With an increase of ion concentration in environment, ion adoption increases too, untill a certain point. In the beginning, ion adoption significantly grows, and after a period of time, it drops. In the first phase of glass dissolution, release rate of elements is the greatest. At first, there is ion exchange between a glass network modificator and $\mathrm{H}_{3} \mathrm{O}^{+}$ions from solution. During the hydrolysis process of glass network, $\mathrm{PO}_{4}{ }^{3-}$ ions are separated from glass network. Hydrolysis is a very quick process that occurs almost simultaneously with ion exchange. Necessary elements for plant growth, including alkali metals, earth-alkali metals, microelements $\left(\mathrm{Zn}, \mathrm{Mn}, \mathrm{Fe}\right.$ and $\mathrm{Cu}$ ) and $\mathrm{PO}_{4}{ }^{3-}$ ions, are released from glass in this way. The release of these elements in the initial stages of plant development is of crucial importance, both for the development of the above-ground mass and for root development. Their uptake by plants is further conditioned by $\mathrm{pH}$ values of the substrate, the temperature of the substrate and watering regime. The optimum $\mathrm{pH}$ of the substrate (5.6-6.35) provides the smooth adoption of the two most important macronutritients, which contributes to the above-ground mass growth.

\subsection{Biomass production}

Application of polyphosphate glasses on $\left(1 \mathrm{gl}^{-1}\right.$ and $2 \mathrm{gl}^{-1}$ ) in substrata increased the average above-ground mass of the investigated plant seedlings (Fig. 6 and Fig. 7). For pepper seedlings with addition of glass $\left(1 \mathrm{gl}^{-1}\right.$ and $\left.2 \mathrm{gl}^{-1}\right)$, the obtained above-ground masses (14.374 $\mathrm{g}$ and $13.866 \mathrm{~g}$ respectively) were greater than the average masses achived by using mineral fertilizers (1.70 g-6.93 g) [28].
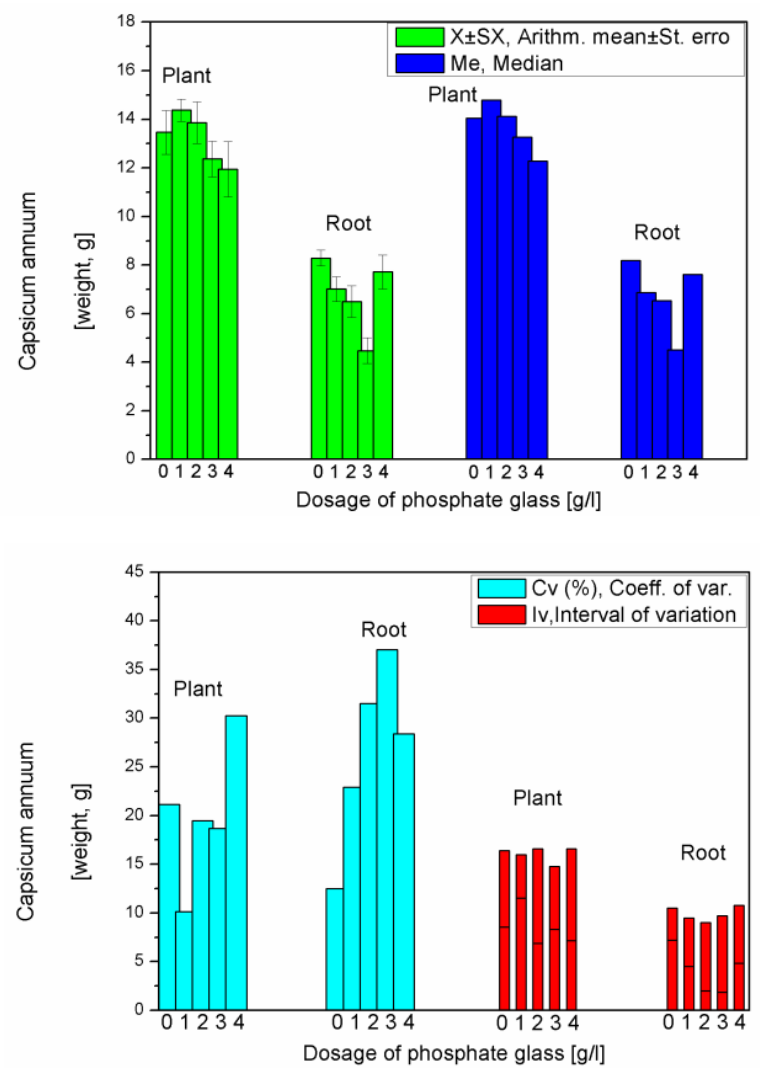

Figure 6. The basic statistical indicators for the examined parameters of the quality of pepper plant seedlings (Capsicum annuum L.)

Slika 6. Osnovni statistički pokazatelji za ispitivane parametre razvijenosti biljaka paprike (Capsicum annuum "Župska rana") kod primene različitih doza fosfatnog stakla

In case of marigold with addition of glass $\left(1 \mathrm{gl}^{-1}\right.$ and $2 \mathrm{gl}^{-1}$ ) the average above-ground mass $(12.594 \mathrm{~g}$ and $12.225 \mathrm{~g})$ attained was equal to the above-ground mass determined for marigold with addition of Scotts-slow release fertilizers using dosage of $4 \mathrm{gl}^{-1}$ into substrate [29]. Similarly, above-ground masses of the marigold were in agreement with results of the effect of polyphosphate glass used in previous studies $[30,31]$.

Above-ground masses of pepper and marigold were $10-35 \%$ higher with addition of $1 \mathrm{gl}^{-1}$ glass than those of the control group (without glass addition).

In addition to nitrogen, phosphorus has a great influence on development of the above-ground mass (branches and leaves) and root of young plants [32]. Lack of phosphorus in the soil leads to the poor development of the root system and above-ground mass. 

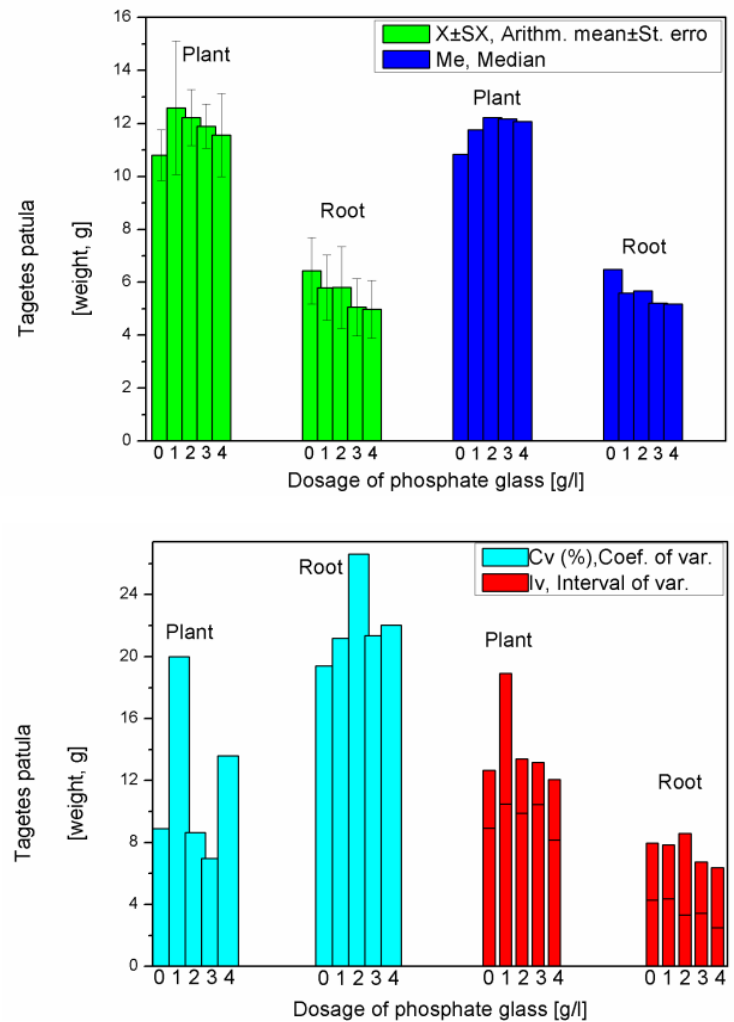

Figure 7. The basic statisticals indicators for the examined parameters of the quality of plant seedlings of marigold (Tagetes patula L.)

Slika 7. Osnovni statistički pokazatelji za ispitivane parametre razvijenosti cveća kadifice (Tagetes patula L.) kod primene različitih doza fosfatnog stakla

Flowering is worse and fruiting is delayed, thereby reducing the overall yield. The need for phosphorus and potassium in nursery flowers is almost equal. Potassium is considered as a "functional element". It affects the maintenance of the osmotic potential in cells and tissues. It is responsible for elongation of the cells, ie. their growth. Most of potassium accumulates in tissues of plants where the intense cell division takes place (root, stem and leaves). Maximum average root mass of marigold $(6.440 \mathrm{~g})$ and pepper $(8.291 \mathrm{~g})$ was determined for the control sample (without addition of glass) and the lowest value $(4.982 \mathrm{~g})$ was attained for glass dosage of $4 \mathrm{gl}^{-1}$. The lowest average root mass of pepper $(4.518 \mathrm{~g})$ was determined for glass dosage of $3 \mathrm{gl}^{-1}$. Maximum average root mass determined for both plant control samples was a consequence of the root elongation due to insufficiency of nutrition elements in substrata.

In order to rank the effects of different dosages of polyphosphate glass on the examined parameters of plant development, the values of the
Ivanovic distances were calculated (Fig.8). For both species, the over-ground masses were used as the most significant indicators of plant development.
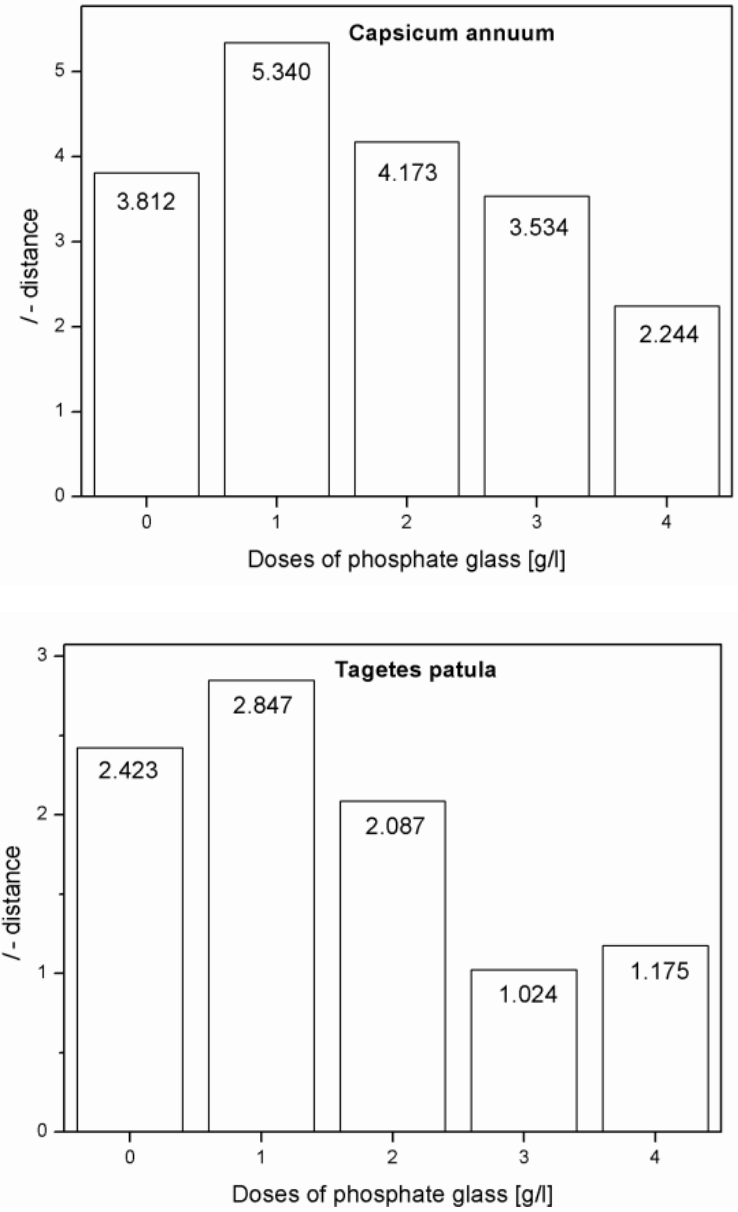

Figure 8. The values of I distances for the quality of Capsicum annuum and Tagetes patula seedlings

Slika 8. Vrednosti I parametara kvaliteta rasada paprike (Capsicum annuum) i kadifice (Tagetes patula)

Regarding the achieved average values for the above-ground mass in both investigated species, as shown in Fig. 8, the obtained values indicate that the best quality of marigold and pepper seedlings was attained with polyphosphate glass dosage of $1 \mathrm{gl}^{-1}$. By increasing the dosage of glass, the development of marigold seedlings decreased. In the case of pepper seedlings by application of glass dosage of $2 \mathrm{gl}^{-1}$, the plants with better characteristics were obtained in comparison to the plants grown without glass addition in substrate. In contrast to the quality of seedlings grown without glass addition, the seedlings of lower quality were obtained with glass dosages of 3 and $4 \mathrm{gl}^{-1}$. 


\section{CONCLUSIONS}

Inorganic fertilizers are immediately available to plants, but they are subject to leaching, a process that occurs when fertilizers are washed by rain or irrigation water below the level of plant roots.

To obtain new kind of fertilizers for application in agriculture, the phosphate glass of the system $\mathrm{P}_{2} \mathrm{O}_{5}-\mathrm{K}_{2} \mathrm{O}-\mathrm{CaO}-\mathrm{MgO}-\mathrm{SiO}_{2}$ was synthesized. The studied glass dissolves without residue and relatively slowly, which benefits the development of plants. The results show that the weight loss at the beginning of the process was linear with time. For longer periods of time, the rate of dissolution decreased. The whole process in an acid solution was 10 times faster than in the neutral environment. This offers the possibility of much more rapid release of nutrients from the glass necessary for plant nutrition. Regarding the parameters analyzed, the glass dosage of $1 \mathrm{gl}^{-1}$ showed the best effect on the investigated plant seedling growth. Designing the glass composition provides the wide range of possibilities for application, and this allows us, for each selected cultivated species, to obtain specific glass compositions and enable the balanced nutrition throughout the entire production cycle.

Taking into account the optimum $\mathrm{pH}$ values of substrates for the development of plant species selected and the length of the vegetation growth, this may mean that such a glass composition can be designed, which will allow the release of the necessary nutrients for a particular stage of development. Glassy fertilizers can contain a complete set of macro and microelements needed for plant growth. Due to the chemical composition and glass form, these compounds are to a minimum degree dissolved in atmospheric water, which is a major shortage of inorganic and organic fertilizers. This feature prevents the rinsing of nutrients from the soil, so that glassy fertilizers do not contaminate groundwater and make them environmentally safe.

\section{Acknowledgments}

The authors are grateful to the Ministry of Education and Science, Republic of Serbia for financial support (Projects TR 34001 and OI 172004).

\section{REFERENCES}

[1] G.Hazra (2006) Different Types of Eco-Friendly Fertilizers: An Overview, Sustainability in Environment, 1(1), 54-70.

[2] J.A.Camargo, A.Alonso (2006) Ecological and toxicological effects of inorganic nitrogen pollution in aquatic ecosystems: A global assessment, Environment International, 32, 831-849.
[3] R.N. Roy, A. Finck, G.J. Blair \& H.L.S. Tandon (2006) Plant nutrition for food security: A guide for integrated nutrient management. FAO Fertilizer and Plant Nutrition Bulletin, 16.

[4] W. Vogel (1985) Chemistry of glass, American Ceramic Society, Columbus, Ohio.

[5] L.L. Hench, R.J. Splinter, W.C. Allen, T.K. Greenlee (1972) Bonding mechanisms at the interface of ceramic prosthetic materials. J. Biomed. Mater. Res. Symp., 2, 117-141.

[6] L.L. Hench (1977) La fabricazione dei bioceramici. Ceramurgia, VII, 5, 253-266.

[7] Y. Zhang, J.D. Santos (2000) Crystallization and microstructure analysis of calcium phosphatebased glass ceramics for biomedical applications. J. Non-Cryst. Solids, 272, 14-21.

[8] I. Waclawska, M. Szumera (2009) Reactivity of silicate-phosphate glasses in soil environment. Journal of Alloys and Compounds, 468, 246-253.

[9] G.Karapetyan, K.Karapetyan, L.Maksimov (2004) Glassy environmentally friendly fertilizers of prolonged action. Phosphorous Research Bulletin, $15,60-67$.

[10] R.K. Brow (2000) Review: The structure of simple phosphate glasses. J Non-Cryst Solids, 263-264, 128.

[11] J.C. Cole, M.W. Smith, C.J. Penn, B.C. Cheary, K.J. Conaghan (2016) Nitrogen, phosphorus, calcium, and magnesium applied individually or as a slow release or controlled release fertilizer increase growth and yield and affect macronutrient and micronutrient concentration and content of fieldgrown tomato plants. Sci Hortic., 211, 420-430.

[12] J.C. Knowles, K. Franks, I. Abrahams (2001) Investigation of the solubility and ion release in the glass system $\mathrm{K}_{2} \mathrm{O}-\mathrm{Na}_{2} \mathrm{O}-\mathrm{CaO}-\mathrm{P}_{2} \mathrm{O}_{5}$, Biomaterials, 22, 3091-3096.

[13] S. Chenu, U. Werner-Zwanziger, C. Calahoo, R. Zwanziger (2012) Structure and properties of $\mathrm{NaPO}_{3}-\mathrm{ZnO}-\mathrm{Nb}_{2} \mathrm{O}_{5}-\mathrm{Al}_{2} \mathrm{O}_{3}$ glasses. J Non-Cryst Solids, 358, 1795-1805.

[14] M.B. Tošić, J.D. Nikolić, S.R. Grujić, V.D. Živanović, S.N. Zildžović, S.D. Matijašević, S.V. Ždrale (2013) Dissolution behavior of a polyphosphate glass into an aqueous solution under static leaching conditions. J Non-Cryst Solids, 362, 185-194.

[15] A.A. Belyustin, M.M. Shultz (1983) Cation Interaction and Associated Processes in Surface Layers of Alkali Silicate Glasses Treated with Aqueous Solutions. Glass Phys Chem.,9, 3-27.

[16] P.J. Melling, A.R. Allantt. (1980) Modelling of leaching and corrosion of glass. J Non-Cryst Solids, $42,553-560$.

[17] S. Gin, J.P. Mestre (2001) SON 68 nuclear glass alteration kinetics between $\mathrm{pH} 7$ and $\mathrm{pH} 11.5$. J Nucl Mater., 295, 83-96.

[18] A. Leidieu, F. Devreux, P. Barboux, L. Sicard, D. Spalla (2004) Leaching of borosilicate glasses. I. Experiments. J Non-Cryst Solids, 343, 3-12.

[19] T. Geisler, A. Janssen, D. Scheiter, T Stephen, J. Berndt, A. Putnis (2010) Aqueous corrosion of 
borosilicate glass under acidic conditions: A new corrosion mechanism. J Non-Cryst Solids, 356, 1458-1465.

[20] N. Lakić, S. Stevanović (2003) Ranking of Vojvodina municipalities according to multidimensional denominator of livestock production commodities. J Agric Sci Resesrch, 48, 217-226.

[21] B. Ivanovic (1973) A method of establishing a list of development indicators, United Nations educational, scientific and cultural organization, Paris.

[22] B. Ivanovic (1977) Classification Theory, Institute for Industrial Economic, Belgrade.

[23] A. Helebrant, B. Tošnerová (1989) A mathematical model used to compare glass durability tests under different flow conditions. Glass Technol., 30, 220223.

[24] H. Takebe, Y. Baba, M. Kuwabara (2006) Dissolution behavior of $\mathrm{ZnO}-\mathrm{P}_{2} \mathrm{O}_{5}$ glasses in water. J Non-Cryst Solids, 352, 3088-3094.

[25] J.C Knowles, K. Franks, I. Abrahams (2001) Investigation of the solubility and ion release in the glass system $\mathrm{K}_{2} \mathrm{O}-\mathrm{Na}_{2} \mathrm{O}-\mathrm{CaO}-\mathrm{P}_{2} \mathrm{O}_{5}$. Biomaterials, 22, 3091-3096.

[26] D.S. Brauer, C. Russel, L. Wu, S. Habelitz (2006) Effect of degradation rates of resorable phosphate invert glasses on in vitro osteoblast proliferation. $J$ Biomed Mater Res A.; 77A, 213-219.

[27] A. Gauthier, J.H. Thomassin (2007) Synthesis of hydroxyapatite during glassy matrix dissolution: influence of their chemical composition. Int J Appl Ceram Technol., 4, 367-377.
[28] V. Bjelić, Đ. Moravčević, D. Beatović, S. Jelačić (2009) Investigational results of new substrate in pepper nursery plants production, XXIII Conference of Agronomist, veterinarians and technologiest, Institut PKB Agroekonomik. Belgrade, Serbia, The Book of Abstracts, p. 113119.

[29] A. Vujošević, N. Lakić, D. Beatović, S. Jelačić, S. Lazarević (2007) Effect of differente of slowdisintegrating fertilizers on the nursery-stock quality of African Marigold (Tagetes patula L.) and Scarlet Sage (Salvia splendens L.). J Agric Sci., 52, 105113.

[30] A.M. Vujošević, M.B. Tošić, N.S. Lakić, J.D. Nikolić, V.D. Živanović, S.D. Matijašević, S.N. Zildžović (2012) Application of phosphate glass in the production of Impatiens (Impatiens walleriana L.) seedlings, $2^{\text {nd }}$ Symposium on Horticulture In Europe, Angers, France, The Book of Abstracts, p. 82- 83.

[31] A.M. Vujošević, N.S. Lakić, J.D. Nikolić, V.D. Živanović, S.D. Matijašević (2014) Application of phosphate glass in the production of flower and vegetable, 5th Int. Scientific Agricultural Symposium, Agrosym. Jahorina, Bosnia and Herzegovina, The Book of Abstracts, p. 269-279.

[32] W. Radin, P. Eidenbock (1984) Hydraulic conductance as a factor limiting leaf expansion of phosphorus deficient cotton plant. Plant Physiol.,77, 372-377.

\title{
IZVOD
}

\section{EFEKAT PRIMENE POLIFOSFATNOG STAKLA U SUPSTRATIMA ZA GAJENJE CVEĆA I POVRĆA}

\begin{abstract}
Polifosfatno staklo, u kome je molski odnos $\left(\mathrm{M}_{2} \mathrm{O}+\mathrm{MO}\right) / \mathrm{P}_{2} \mathrm{O}_{5}>1$, koje sadrži i mikroelemente $\mathrm{Zn}^{2+}, \mathrm{Mn}^{2+}, \mathrm{Fe}^{3+} i \mathrm{Cu}^{2+}$, korišćeno je u supstratu za proizvodnju rasada cveća i povrća. Eksperimenti su izvedeni u stakleniku na Poljoprivrednom fakultetu u Beogradu i u laboratorijama ITNMS. Ispitivano je ponašanje polifosfatnog stakla prilikom rastvaranja u dejonizovanoj vodi i $2 \%$ rastvoru limunske kiseline na temperaturama od 20, 30, 37 i $50{ }^{\circ} \mathrm{C}$. Ispitan je uticaj vremena rastvaranja na normalizovani gubitak mase $\left(f_{m}\right)$ i normalizovane koncentracije jona (fi). Određene su $i$ konstante brzina rastvaranja( $k_{w}$-dejonizovana voda, $k_{c}-2 \%$ rastvor limunske kiseline). Vrednosti $k_{c}$ su veće od vrednosti za $k_{w}$, što potvrđuje uticaj rastvarača $i$ temperature na proces rastvaranja. Rezultati su pokazali pozitivan efekat polifosfatnog stakla na rast $i$ kvalitet ispitivanih biljaka. Primenjena doza polifosfatnog stakla od $1 \mathrm{gl}^{-1}$ pokazala je najbolji efekat na rast ispitivanih biljaka-rasada
\end{abstract}

Ključne reči: polifosfatno staklo, supstrat, biljka, rasad.

\author{
Naučni rad \\ Rad primljen: 02.12. 2018. \\ Rad prihvaćen: 12. 01. 2019. \\ Rad je dostupan na sajtu: www.idk.org.rs/casopis
}

(C) 2019 Authors. Published by Engineering Society for Corrosion. This article is an open access article distributed under the terms and conditions of the Creative Commons Attribution 4.0 International license (https://creativecommons.org/licenses/by/4.0/) 